\title{
Initial Design of Forging Measuring Instrument for Application of Friction Welding
}

\author{
Bagus Muhammad Fauzi ${ }^{1}$, Irza Sukmana ${ }^{1, *}$, Yanuar Burhanuddin ${ }^{1}$ \\ ${ }^{I}$ Department of Mechanical Engineering, Faculty of Engineering, Universitas Lampung Jl. Prof. Dr. Sumantri Brojonegoro \\ No. 1, Bandar Lampung, Indoneisa \\ *Corresponding Author: irza.sukmana@gmail.com
}

\section{Article history}

Received: 12-01-2020

Revised: 16-02-2020

Accepted: 15-03-2020

DOI: $10.31629 /$ jit.v1i1.2129

\begin{abstract}
Friction welding is a metal joining technique without melting beforehand in which the process is to combine the rotation rate in one of the work materials. In the previous studies, the forging pressure parameters used for friction welding did not have a definite reference to the strength of the joint in friction welding. This project is to make initial design of forging measuring instrument for application of friction welding. The steps include conceptual design, embodiment process, and performance analysis. The conceptual design result includes hollow iron U-shape, telescopic iron, and telescopic iron with screw. The measuring system uses a $500 \mathrm{~kg}$ load cell, Arduino Leonardo, HX711amplifier, and data logger. Then, after all components are assembled, the load cell calibration is performed to determine the calibration factor. The next stage is to do pressure test to see the performance of forging measuring instrument of friction welding.
\end{abstract}

Keywords: friction welding, load cell, HX711 amplifier, Arduino

\section{Introduction}

Friction welding is one of the metals joining techniques that is hard to do with liquid welding method. In friction welding, metal joining process is without melting the metal beforehand, in which the process is to combine the rotation rate in one of the work materials. The rotation of friction in one of the working materials will heat and melt both joints thus causing joining process as highlighted by others $[1,2]$.

In the previous study, friction welding used for joining iron and stainless steel, with additional forging pressure parameter [2]. However, forging pressure used still did not have an accurate reference to the strength of the joint yet. Another study also shows that friction welding did not use forging parameter but time- contact and rotation speed parameter, thus making the connection quality of this friction welding is most probably affected by pressure during welding process [3].

\section{Literature Review}

\subsection{Strain Gage}

Strain Gage is a passive transducer that converts mechanical friction into resistance one. As pressure and tension are measured, resistance of wire foil (thin tin or silver) changes its length. If one of materials at the gage is attached, it will cause strain or pressure. It is this conversion that is measured with Wheatstone bridge and the output pressure resulted is made as force reference received by load-cells. 


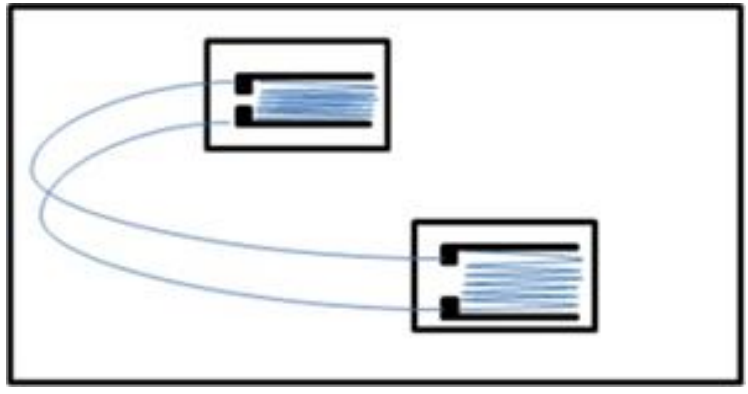

Figure 1. Strain Gage

\subsection{Load Cell}

Load cell is a transducer to measure force by measuring deflection caused by that force. Load Cell is the core component in digital scale. The sensory component in the load cell used to measure deflection is strain gauge.

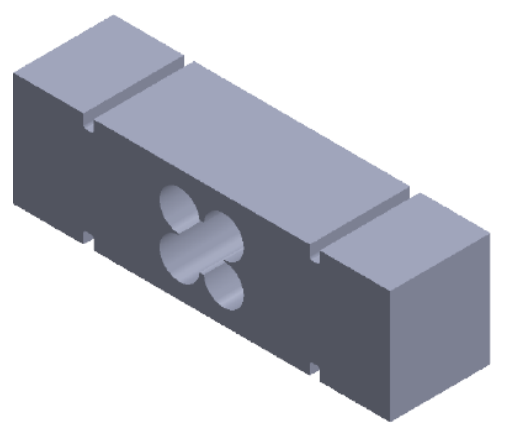

Figure 2. Load Cell

\subsection{Micro Controller}

Micro controller is a complete microprocessor system in a chip. Micro controller is different from multi-function one in a PC because a typical micro controller contains with supporting components of a minimal microprocessor system, that is, memory and programming of Input-Output. Micro controller is capable for programming to operate a calculation, accepting input and generating output. Micro controller contains with core processor, memory, and programming of Input-Output.

\section{Research Methodology}

Initial Design of Forging Measuring Instrument for Application of Friction Welding is divided into some phases, namely: conceptual design, embodiment process, and analysis of performance. In conceptual design, there are processes to follow, namely:

\subsection{Making Conceptual Design}

This phase is how the concept is made based on the planning list and its duties. The concept is the solution of the planning that must be solved.

\subsection{Selecting Conceptual Design}

Selecting concept is aimed at continuing to the phase of embodiment design, in which the best concept is selected on the basis of the availability of the materials, fabrication, the cost of making components, capability of assembling, operating, and maintaining.

\subsection{Embodiment of conceptual design}

After passing some planning phases above, the next phase is developing the selected concept one based on early requirement, changing into 3dimension design using CAD application (Computer Aided Design) Solidwork 2016.

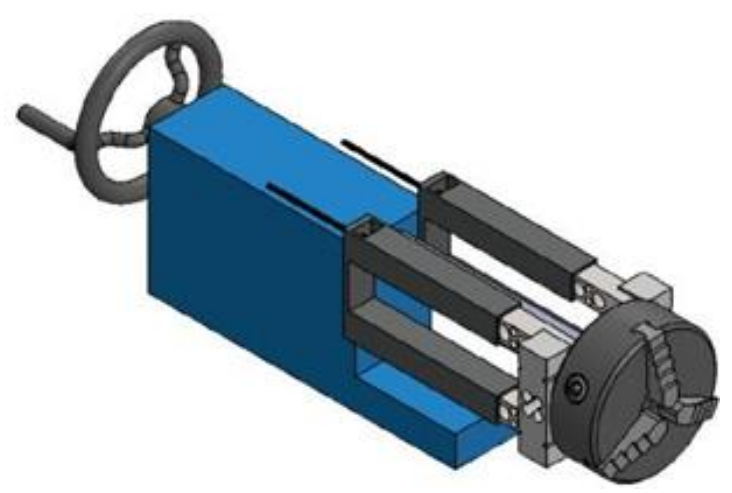

Figure 3. Concept of Forging Measurement Tool for Friction Welding

\subsection{Planning of Main Component}

In the planning process of forging measurement tool, friction welding consists of four main components. It is necessary to analyze their force before the actual operation starts. These components include hollow U iron, telescopic, telescopic iron with screw, and Arduino system. Arduino system is component that operates load cell as forging measurement tool for friction welding $[4,5]$. 


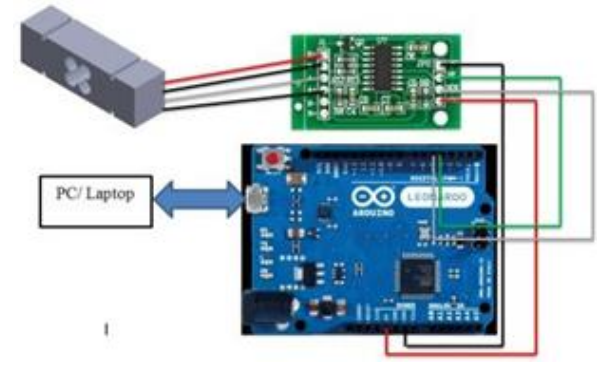

Figure 4. Scheme of Face Tracking Diagram using Arduino System

The next phase is embodiment process, as the continuation of conceptual design phase. This phase is aimed at identifying the force of selected concept in the previous phase. The output of this phase is the form of tool frame that has been assembled and tested by forging measurement tool.

Analysis of performance phase will show the test result of forging measurement tool of friction welding. It will add positive and negative points of friction welding.

\section{Results and Discussion}

\subsection{Process of Embodiment}

This is continual phase of conceptual design. It aims at assessing whether or not forging measurement tool of friction welding capable of processing trial data by calibrating height using height scale and testing with wood and magnesium AZ31B. Prior to this phase, the third concept to develop has been chosen. This concept is superior as it has unattached load cell mechanism so as to pull and press the force optimally. This third concept has some components, namely: hollow iron U, telescopic, telescopic iron with screw, and load cell.

The following is the result of calibration value and forging measurement tool testing [6].

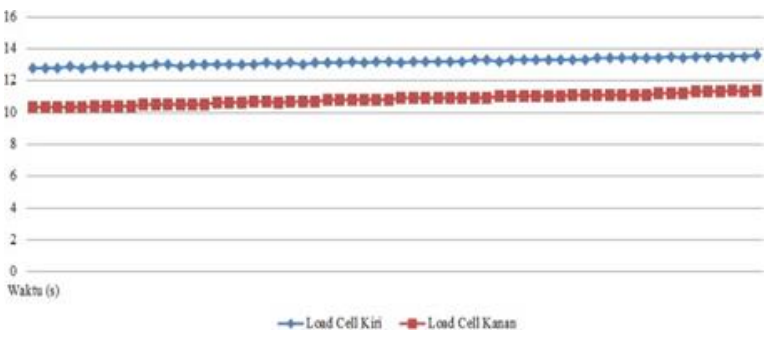

Figure 5. Calibrated Value Graphic of Forging Measument Tool of friction welding
This trial test shows that the calibrated value of load cell on the left is 430,00 with approximate output value of $1,07 \mathrm{~kg}$. If calibrated value is elevated to 440,00 , the result will be less satisfactory as its approximate value is less than $1 \mathrm{~kg}$ of the height scale. This value is derived from 1 minute trial test of load cell. While, the calibrated value of load cell on the right is 970,00 with approximate value of $0,997 \mathrm{~kg}$. This calibrated value is bigger than on the left one due to their difference in shape. However, their maximal height value is the same, that is, $500 \mathrm{~kg}$. The load cell on the right has more satisfactory value as it generates a more stable trial testing, that is, $1 \mathrm{~kg}$.

After calibrated value was performed to find out each calibration in each load cell, then the actual testing on wood and magnesium AZ31B was performed. Firstly, testing on wood was performed to find out the measurement force on highly elastic materials. To make it as an actual condition, a specimen was tried on lathe to find out the force of forging measurement tool of friction welding. The result showing forging testing on wood as on Figure 6.

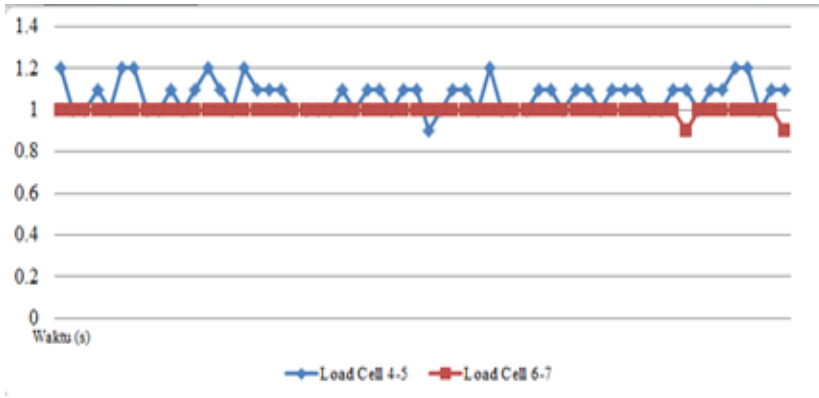

Figure 6. Forging Testing on Wood

Forging testing on wood shows that the output value of load cell on the left is $128.3717 \mathrm{~kg}$ with calibrated value of 430.00 . It is bigger than the output value of load cell on the right, that is $53.33833 \mathrm{~kg}$ with calibrated value of 970.00 .

Further testing on Magnesium AZ31B was performed. It is already known that magnesium is one of the materials used in friction welding process. The size of magnesium used in this testing is $141 \mathrm{~mm} \times 132 \mathrm{~mm} \times 56 \mathrm{~mm}$. The tested object is attached to the chuck so as to generate optimal force. The following is graphic and table of forging measurement tool using Magnesium AZ31. The result is presented on Figure 7. 


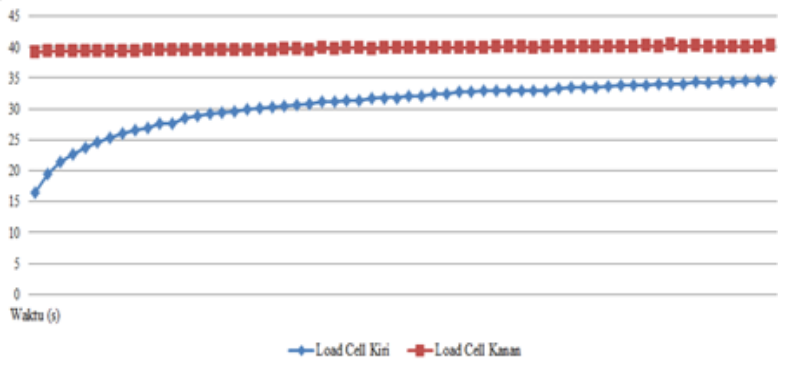

Figure 7. Graphic of Forging measurement using Magnesium

Forging testing shows that the output value of load cell on the left is approximately $211.935 \mathrm{~kg}$ with calibrated value of 430.00 . While, the output value of load cell on the right is approximately $155.1867 \mathrm{~kg}$ with calibrated value of 970.00 . It tells us that the output value of load cell on the right is higher than the forging testing using magnesium AZ31B [7,8].

\subsection{Analysis of Performance}

This phase is the continuation of embodiment process which aims at analyzing working and performance of forging measurement tool of friction welding. There are two important points of positive and negative ones for this forging measurement tool of friction welding [9].

It can be resume that the tool is capable for improvement on acquisition of Arduino data system by conversion on datalogger component. Related to moving mechanism, greasing can be added to ease forward and backward movement. By doing so, a more optimal data collection using datalogger software will work well in doing acquisition of forging data process. For the accuracy of tool when performing forging, the testing indicates an excellent description as it is capable of generating force. However, there is still problem with the weight of tool that needs solution to decrease its weight $[8,9]$.

\section{Conclusion}

Conceptual design of forging measurement tool of friction welding uses mechanism of telescopic iron, screw locking method at the top part, and loose mechanism at down part. This concept is the best to the extent of its capacity, accuracy, operation, and maintenance. Forging testing on wood at load cell on the left generates $128.3717 \mathrm{~kg}$ with calibrated value of 430.00 and load cell at the right generates $53.33833 \mathrm{~kg}$ with calibrated value of 970.00. Forging testing on Magnesium AZ31 at load cell on the left generates $211.935 \mathrm{~kg}$ with calibrated value of 430.00 and at load cell on the right generates $155.1867 \mathrm{~kg}$ with calibrated value of 970.00 . The differences of model design between load cell on the left and load cell on the right also cause differences of calibrated value, yet both load cells have the same maximum forces of $500 \mathrm{~kg}$.

\section{Acknowledgement}

Authors would like to express gratitude for the financial support from BLU Universitas Lampung Hibah Kerjasama Luar Negeri (KLN) TA2019 as well as Hibah DIPA FT Unila 2019.

\section{References}

[1] A. F. Ardianto. 2015. Kekuatan puntir sambungan las gesek Al-Mg-Si dengan variasi sudut chamfer dua sisi dan kekasaran. Univ. Brawijaya. Malang.

[2] A. K. Nasution et al. 2014. Partially degradable friction-welded pure iron-stainless steel 316L bone pin. Faculty of Biosciences and Medical Engineering, Universiti Teknologi Malaysia, Johor Bahru 81310, Malaysia.

[3] Solihin. 2016. Pengaruh Kecepatan Putar Dan Waktu Kontak Pada Friction Welding Magnesium AZ31 Terhadap Kualitas Sambungan Las, Jurusan Teknik Mesin, FT Universitas Lampung.

[4] R. Magga. 2011. Penggunaan Strain Gage (Load Cell) Untuk Analisa Tegangan Pada Pembebanan Statik Batang Aluminium. Jurusan Teknik Mesin, Fakultas Teknik, Universitas Tadulako.

[5] O. Handinata. 2012. Pengembangan Rancang Bangun Alat Pengukur Indeks Massa Tubuh Berbasis Atmega8535 Dan Databasenya Berbasis PC, Jurnal Fisika, Fakultas MIPA, Universitas Sumatera Utara.

[6] D. Nurcahyono. 2017.Analisis Kalibrasi Load Cell Tarik Tipe Pancake Dengan Metode Kalibrasi Tekan. Pusat Penelitian Metrologi-LIPI. Banten.

[7] R. Nuryanto. 2015. Pengukur Berat dan Tinggi Badan Ideal Berbasis Arduino. Karya Ilmiah Program Sarjana. Surakarta: Universitas Muhammadiyah Surakarta.

[8] I. Oktariawan. 2013. Pembuatan Sistem Otomasi Dispenser Menggunakan M ikrokontroller Arduino Mega 2560. Jurusan Teknik Mesin, Fakultas Teknik, Universitas Lampung.

[9] J. K. Gupta and R. S. Khurmi. 2005. A Text Book of Machine Design, Ram Nagar, New Delhi. 